Original scientific paper

UDK: $327.5: 316.48$

DOI: $10.5937 /$ jrs $15-24562$

Received: 23 December 2019 / Accepted: 18 March 2020

\title{
Geopolitics: The Seen and Unseen in Small State Foreign Policy*
}

\author{
MARI-LIIS SULG** \\ University of Tartu, Estonia \\ MATTHEW CRANDALL \\ Tallinn University, Estonia
}

\begin{abstract}
Geopolitics, a combination of geography and politics by default resembles the power politics of large states. As small states have little resources to pursue power-based foreign policy, one can wonder if the geopolitics of small states matter. This paper argues that small states use geopolitical tools to locate themselves on the winners' side. The current paper takes a closer look into the post-Cold War foreign policies of Estonia and Finland that originate from opposite principles. Estonia's principle of „never alone again“, locates itself in the West. This differs from its neighbour Finland's principle "always alone“, which locates itself as a strategic regional actor. To highlight the same but somewhat different reasoning in their foreign policies, the annexation of Crimea and the war in Ukraine are studied in this article by applying critical geopolitics as a methodological tool.
\end{abstract}

Keywords: critical geopolitics, small state, foreign policy, Estonia, Finland

\section{Introduction}

The combination of small states and geopolitics offers a set of concepts that have wide meanings. Although both, small states and geopolitics as concepts were taken into use long ago in the history of international relations, a consensus has not formed about the applied meaning of either concept. Both concepts, small states and geopolitics reflect socially constructed, preferred perceptions and unseen messages.

After the end of the Second World War, the role of a small state as an actor in international relations has gained more attention due to the rising number of small states and their growing importance and visibility in the international arena. That tendency has brought small states into the focus of international relations and small state scholarship has gained a remarkable role in it. After becoming familiar with the small state studies literature,

\footnotetext{
* An earlier version of this article was presented at the 13th Pan-European Conference on International Relations (EISA 2019) held in Sofia University „Sveti Kliment Ohridski”, Bulgaria. We wish to thank dr Matti Pesu from FIIA for his constructive feedback.

*mariliis.sulg@edk.edu.ee
} 
starting with the Melian dialogue from the fifth century $\mathrm{BC}$, one could conclude that there still is no single and grounding definition for what a small state is. Despite several attempts to frame the small state concept, it remains a contested term that can be interpreted in many ways. According to $\mathrm{Hey}^{1}$ and $\mathrm{Knudsen}^{2}$, the concept of small state should not be taken as a level of analysis but rather as a focusing tool that is the approach this article follows.

Geopolitics, on the other hand, seems to have meaning that is more precise by reflecting the interplay of geography, politics, and power. Geopolitical thinking, as a scholarship, born out of the lack of land to colonialize, took the direction of spatializing the international arena as a space where politics could step into with the help of geography. This article sees geopolitical space as an international arena where states apply their foreign policies with the help of geopolitical reasoning. If large and powerful states have the luxury of creating the geopolitical space then small states are the ones who follow it. Thus, the geopolitical space is seen as an arena for large and powerful states that the small states have to adapt with or to follow. If great powers apply their geopolitical vision, then small states have to use the tools they can to locate themselves on the winners' side. Thus, this article applies the concept of geopolitical space as an unseen interstate area where states aim to serve their interests in the best possible way by constructing foreign policy narratives, establishing alliances and fulfilling their foreign policy goals by implementing selected narratives to achieve certain goals. This article argues that small states are not just inertly standing in geopolitical space, but can actively position themselves, and do so in their foreign policies that are studied in this article on the example of Estonia and Finland.

Since Estonia regained its independence in 1991, it has pursued a foreign policy agenda that can be summed up with a principle and a goal "never alone again" which has meant maximum integration intending to locate itself into West. Finland preserved its independence after the Continuation War against the Soviet Union and this has been the foundation for its foreign policy agenda that can be summed up as "always alone" which has meant having strategic relations and dialogue with Russia, also after the EU membership.

Although both, Estonia and Finland are members of the EU and support the post-Crimean EU sanctions towards Russia, some differences remain in their foreign policy reasoning. The differences in reasoning will be presented with the help of applying practical geopolitical reasoning as a methodological tool. This article seeks to better understand the geopolitical reasoning of the two countries' post-Cold War foreign policies by focusing on how both small states perceived the understanding of the "winning side". After learning about the foreign policy reasoning towards the crisis in Ukraine, the narrow and wider impact of the Ukrainian crisis on both country's foreign policy is analysed. Thus, this article takes a closer look at the positioning of Estonia and Finland in post-Cold War geopolitical space and offers a comparative understanding of how the annexation of Crimea and

1 Hey 2003, 3-11.

2 Knudsen 1996. 
the war in Eastern-Ukraine have influenced their foreign policies. To better highlight both countries' perceptions towards the crisis in Ukraine, the geopolitical reasoning of the foreign policies of Estonia and Finland towards the War in Ukraine and the annexation of Crimea in 2014 are studied in depth. Estonia and Finland have been selected as objects of the study as they are two neighbouring small states, which share common threat perception towards Russia but carry different reasoning on how to deal with the threatening neighbour. Two countries that have had different pasts have also developed a different strategy in their foreign policy: Estonia being a strategically vocal transatlantic small state and Finland a strategically silent, politically aligned, but militarily non-aligned strategic small state. The annexation of Crimea was selected as a case that presents a moment where Estonia and Finland did not agree upon the events in international politics and had to apply their geopolitical means to adapt to it. Besides, it presented a moment for Estonia where the previously achieved security guarantees did not seem enough. For Finland, it was a moment to take the stand between the East and West. The foreign policy concepts of both countries are studied together with articles reflecting the foreign policy reasoning of foreign-policy makers from both countries. This will demonstrate how the two neighbouring small states adapted to the changing security environment and what kind of geopolitical tools they applied. To accomplish the task, this article applies the model of practical geopolitical reasoning of critical geopolitics, developed by G. O'Tuathail. ${ }^{3}$ The geopolitical grammar of practical geopolitical reasoning, developed by O'Tuathail is a set of five questions (Where/What/Who/Why/So what?) that helps the researcher to conceptualize foreign policy thinking towards a certain crisis. The model will be introduced in more detail later in the article. To understand the reasoning of both countries' foreign policies and the geopolitical tools used, the guiding questions by O'Tuathail were modified for this research, to be the following:

1) To where do the Ukrainian conflict and the annexation of Crimea locate Estonia/ Finland in geopolitical space?

2) What is the perceived direct threat from the Estonian/Finnish perspective?

3) What is the perceived indirect threat from the Estonian/Finnish perspective?

The article is divided into four main parts, from which the first elaborates on small states as actors in the post-Cold War era. The second describes the choice for practical geopolitical reasoning as a tool to study small state foreign policy. The third part offers a comparative insight into the development of Estonian and Finnish foreign policy thinking including detailed insights into current foreign policy thinking within the changing European security environment. The fourth part introduces empirical findings of the study based on the analysis of both countries' geopolitical reasoning of the annexation of Crimea and war in Eastern Ukraine by highlighting the differences and similarities the two neighbouring small states have. The article concludes by comparing where Estonia and Finland, two

3 O'Tuathail 2002. 
neighbouring small states stand in geopolitical space and also analyses the impact of the annexation of Crimea and the war in Eastern Ukraine on these positions.

\section{Small State Foreign Policy in the Post-Cold War Era}

According to Noreen et al., ${ }^{4}$ the initial wave of small state studies took place during the Cold War and was to a great extent focused on the survival of small states in the bipolar international system, which was dominated by superpowers. The second wave took place in the post-Cold war era and focused on the proliferation of small states globally, and particularly focused on Western Europe and the EU. ${ }^{5}$ Noreen et al. also argue that within the- the second wave of small state studies, small states cannot be generalized only as survival seeking entities anymore, but rather as states with very different ambitions, with significant variations between the small state foreign policies. Vaicekauskaite adds that small states not only differ from bigger states but also differ among themselves, despite sharing similar characteristics, small states do not necessarily pursue the same foreign policies. ${ }^{6}$ Vaicekauskaite offers an example of Denmark as a small state,- an active member of NATO with an image of a transatlantic small state, compared to Finland as a small state, with an image of a rather neutral foreign policy in the region. ${ }^{7}$

Thus, the post-Cold War era small states were able to pursue different foreign policies constructed towards certain international conflicts by using geopolitical reasoning. For example, Noreen et al. build a case of small state foreign policy study, claiming that a small state can also pursue different foreign policies within one country. ${ }^{8}$ They present the example of Sweden, a country with a strong historical tradition of neutrality that was left aside when Sweden built an active foreign policy towards one international crisis and decided to participate as a member of ISAF in Afghanistan from 2002 to 2013. To build a better understanding of Finnish and Estonian (small state) foreign policies the reasoning of the war in Ukraine and the annexation of Crimea have been selected as external "irritators" that determine and direct the foreign policy of a small state. This study finds that international crises serve as unexpected inputs of geopolitical space that affect small states by challenging their expected foreign policy behaviour. To study this, the practical geopolitical reasoning of small state foreign policy is set to be the methodological approach of this study. The practical geopolitical reasoning has been chosen for as it seeks to understand how politicians and foreign policy decision-makers make sense of international crises, how they construct stories to explain the crises, how they develop strategies

$4 \quad$ Noreen et al. 2017.

5 Ibid.

6 Vaicekauskaitè 2017.

7 Ibid.

8 Noreen et al. 2017. 
for handling international crises as political challenges, and how they conceptualize solutions to the crisis. ${ }^{9}$

\section{Critical Geopolitics and Small State Foreign Policy}

Power politics of large states has become more relevant in recent years, leaving small states in a vulnerable position which makes one to ask how small states have adapted to the changing geopolitical environment. As stated above, this article finds that despite the focus on great power politics that create the geopolitical space, small states also pursue foreign policies that aim to position themselves in that space. Thus their different choices and foreign policy lines could be seen as a proof that small state agency matters in shaping the geopolitical space.Therefore, this article adopts critical geopolitics as a methodological approach to study how Ukraine and Crimea impact the foreign policies of Estonia and Finland and how the external input has impacted both states' position in geopolitical space. In more particular, this article applies three questions derived from O'Tuathail's approach derived from his 2002 study $^{10}$ on the United States' response to the war in Bosnia that offers a toolkit of geopolitical grammar to study the practical geopolitical reasoning of states' foreign policy.

To understand the locating of small state foreign policy in geopolitical space, the first question asks instead of O'Tuathail's „Where?/What/Who? "To where?". The formulation of this question aims to understand the perception of the "winning side" on the geopolitical map and the applied geopolitical tools of both countries, thus the to where the question was applied. This substitution aims to better frame the location of Estonia and Finland in geopolitical space, - their constructed foreign policy narratives, preferred locations and ways how they have aimed to achieve these before and after the developments in Ukraine. The second and third question of this research focuses on direct and indirect threat perceptions of Finland and Estonia that aim to substitute O'Tuathail's „Why/So what?". These questions aim to frame a comparative framework between the two countries and to offer an understanding of the perceived direct and indirect threats that affected both countries and resulted in their respective foreign policies.

To apply the practical geopolitical reasoning of Finnish and Estonian foreign policies towards Ukraine and Crimea, the foreign policy concepts of both countries were mapped and analyzed. In Estonia, where the foreign policy is mostly focusing on security, the "Security policy concepts" are published about every seven years, that also serve as foreign policy concepts. In the framework of this research, the one adopted in $2017^{11}$ together with the minutes of annual foreign speeches by the Minister of Foreign Affairs and the

9 O'Tuathail 2002.

10 Ibid.

11 Julgeolekupoliitika alused (Foreign and Security Policy Concept), Ministry of Defence of Estonia, 2017 
Head of Foreign Affairs Committee of the Parliament of Estonia from the 2015, ${ }^{12} 2016,{ }^{13}$ $2017^{14}$ were analysed.

In Finland, there are no central foreign policy concepts adopted after certain periods. Instead, the leaving government submits a report on the state of affairs in Finnish Foreign and Security policies. The one submitted in $2016^{15}$ together with the speeches of the president of Finland were analysed. To categorize the presidential speeches, the selection does not claim to be total but the ones relevant from foreign policy reasoning perspective were included. The following speeches since 2015 were included: Finnish presidential speeches at the UNGA, speeches at the Kultaranta Talks, speeches held on state visits of the presidents of Estonia and Ukraine to Finland; opening speeches for the defence course, and the speeches at annual ambassadorial conferences in Helsinki.

In addition to the analysis of both countries' national foreign policy concepts, speeches, and debates, a brief interview was conducted with the Director of Finnish Institute of International Affairs (FIIA) and a professor of Tallinn University, Dr. Mika Aaltola on July 31,2019 . Both countries' foreign policy documents were analysed by applying the three questions derived from O'Tuathail's geopolitical reasoning.

\section{Foreign Policies of Estonia and Finland: Same Neighbourhood But Different Neighbours}

Although this article focuses on post-Cold War developments, a brief understanding of the history of both countries is necessary to understand the impact of history on the development of current foreign policies. There are many differences and similarities in the foreign policies of Estonia and Finland. To start with the similarities, both were "left alone" in the 1940s that resulted in different outcomes, the annexation of the Baltic states, including Estonia, into the Soviet Union, and the preservation of Finnish independence after multiple wars between the Soviet Union and Finland. The notion of "being left alone" has thoroughly affected both countries' foreign policies and while there is a common ground on sharing the same threatening neighbour, there has, due to the historic experience, evolved a different perception on "how to deal with" the Eastern neighbour Russia. While the Finnish foreign policy is carried by the idea that only dialogue with Russia is the key to rational and strategic relations, the grounding mentality of Estonian foreign policy does not allow trusting the dialogue with Russia. These perceptions, mostly coming from history form the ground that has led them to pursue some differences in their foreign policies. As Estonia was incorporated into the Soviet Union and after that disappeared from the world map as an independent country, it does not have Cold War-period for-

\footnotetext{
12 Parliament of Estonia 2015.

13 Parliament of Estonia 2016.

14. Parliament of Estonia 2017.

15 Government of Finland 2016.
} 
eign policy. Finland, in turn, adopted the foreign policy line entitled "Paasikivi-Kekkonen line" that aimed for a pragmatic relationship with the Soviet Union. ${ }^{16}$ That period also created the term "Finlandization" that stated for neutrality but covered foreign policy of Finland pre-coordinated with Russia. Forsberg and Pesu emphasize that Finlandization should not be oversimplified as a simple Russian control over Finland, but rather as a tool, not an end. They also bring out that for Finland, the Finlandization could be seen from several perspectives - positive, as it helped Finland to remain non-occupied, negative as being remotely controlled by Russia, but also as a political culture that enabled Finland to embrace the principles of totalitarianism without becoming one itself. ${ }^{17}$ During the postCold war era, both countries have valued the EU as the main political identity and priority and both had a goal of becoming a core member of the EU. With the collapse of the Soviet Union, the Finnish-Russian relation had lost its relevance that had slowly shifted from the Gorbachev's glasnost and perestroika policies. ${ }^{18}$ Thus, the foreign policy priorities of Finland were a bit similarly "deliberated" as Estonia from the Soviet occupation and the EU as a political affiliation was adopted. In the case of Estonia, the membership of Western international organizations was adopted as the main aim to confront with its Soviet past. However, the perception of security has been and still is different. Finland has pursued a total defence system that is not based on collective security but territorial defence. This has been supplemented with cooperative partnerships, including NATO's Partnership for Peace Initiative since 1994, participating in joint exercises and also in NATO's missions abroad. ${ }^{19}$ Still, Finland keeps its door open for both, joining NATO or to maintain its militarily non-aligned status.

Another grounding principle in Finnish foreign policy is based on antagonism towards the great power politics, that also, at some level includes the antagonism towards the U.S. Estonia, on the other hand, sees its security guarantee based on its relations with the U.S., the only benevolent superpower that could offer security guarantees to a small state. Thus, Estonia has become one of the core members of NATO fulfilling the $2 \%$ defence spending criteria. Thus Estonia's security perception is strongly built on NATO's collective security that is seen as the ultimate security guarantee after Estonia's territorial defence. The common wisdom of Estonian-Finnish foreign and security policies states that in Estonia's case, the security and defence policies determine the foreign policy and in the Finnish case, the foreign policy determines the security and defence policies. For Estonia, the membership in NATO and the EU are seen as inseparable foundations for "not being alone", but for Finland, the membership of EU and partnership with NATO is kept apart. Thus, the Finnish way of not having the final solution, but rather to distance itself from certain foreign policy issues, is resulting from the "always alone" way of thinking. An interesting difference also appears from the "alone” principles, as "always alone" doesn't constitute an ideal state of affairs for Finland, but as the result of a cynical, realist view on history, while

16 Forsberg and Pesu 2016.

17 Ibid.

18 Ibid.

19 Finnish Defence Forces 
Estonia's "never alone again" stems from an idealist-based view. These somewhat different approaches have played a crucial role in what has been named a strategically vocal Estonia versus strategically silent Finland earlier in this article. Estonia's strategic loudness has been evident first of all in its strong and political support to both, -Georgia and Ukraine, also within sharp words for the support of international law and a rule-based international order by the political leadership of Estonia after the developments in Georgia and Ukraine. Finnish strategical silence stems from its less sharper stand vis-à-vis Russia after the 2008 Russia-Georgia war as Finland, together with the majority of European states, hoped to retain pragmatic relations with Russia. This has been sharply described by Sven Sakkov as "unfortunately the lessons provided by the August war (Georgia) were wasted on most NATO Allies, ... if Georgia was supposed to be an early wake-up call for Europe, most of the continent and North America hit the "snooze" button and continued their vacation in strategic La-La Land“. ${ }^{20}$ When comparing the two states, then Estonia has adopted the role of a judge, and Finland the role of a physician of international relations. This will be elaborated in more detail in the next section.

\section{Finland: A Small State With Pragmatic Foreign Policy, Can It Last Forever?}

Browning and Lehti ${ }^{21}$ have researched the notion of "marginality" in Finnish foreign policy. They find the size of Finland being securitized by president Paasikivi's term until the mid-1950s, as Finnish smallness was used as a way to isolate itself from the Cold War tensions. Marginality was seen as a negative feature at Paasikivi's time as it reflected the reality that Finland had no foreign policy options, thus in parallel with pragmatic relations with the Soviet Union, the Nordic identity was adopted and emphasized by Finland. At the time of Kekkonen's term(s) from the mid-1950s to early 1980s, the smallness of Finland was seen as a rather positive thing that enabled Finland to create the image of a political borderland as it enabled Finland to become a "physician of international relations, not a judge".22

The end of the Cold war and the collapse of the Soviet Union forced Finland to re-calculate its foreign policy. According to Browning and Lehti ${ }^{23}$ the end of Cold War served as a strong catalyst for Western narratives as at the time the marginality was again seen as a negative thing and Finland had to abandon its political border country rhetoric was substituted by "return to Europe/home" that was denied during the Cold war. ${ }^{24}$ Palosaari finds this shift fostered by a reconceptualization of neutrality - as Finland relocated itself from "small state neutrality" to a member state alignment and towards "small EU member-

20 Sakkov 2019.

21 Browning and Lehti 2007.

22 Ibid.

23 Ibid.

24. Ibid. 
stateness".25 In the 1990s as the East-West rift seemed to fade away, the neutral position of Finland lost relevance and was replaced by a strategic decision to become a progressive force and exemplary insider in various international organizations, with full access to information and the capability influencing vital decisions. ${ }^{26}$ That meant joining the EU but this new approach was not extended towards NATO, although partnership level cooperation was adopted. That means that to be on the "winners"' side, Finland engaged politically with the EU but at the same time, it has preserved its "neutrality" by not joining the NATO. Thus, the post-Cold War foreign policy of Finland has shifted from neutrality to political engagement with the West, particularly with the EU. Although the neutrality had lost its importance, it was still accompanied by fostering good relations with Russia that enjoyed wide popularity and elite support in Finland. ${ }^{27}$ According to Haukkala "despite the westward drift in Finnish foreign policy, Russia has by no means lost its significance".28 Russia was seen as a challenge rather than an outright threat. In sharp contrast with the Estonian perspective, Finland sought to support the democratization of Russia within multilateral organizations, which had only a minimal impact by the 2008 Georgian war. ${ }^{29}$ According to Raik et al., the annexation of Crimea opened the discourse in Finnish foreign policy where speaking about Russia as a threat became a part of the official discourse and thereby Finland had anchored itself ever closer to the Western community. In institutional terms, Finnish foreign policymaking rests on the government, as well as the president who is elected through a direct popular vote. ${ }^{30}$ The Finnish constitution grants significant authority over foreign affairs to the president who shares responsibility with the government. ${ }^{31}$ Sauli Niinistö, who has been the president of Finland since 2012, has stated the four pillars of Finnish foreign policy are "national defence and security, western integration, relations with Russia, and the international system, particularly its structure, rule-based nature and manageability". ${ }^{2}$

After the war in Ukraine and the annexation of Crimea, many prominent U.S. geopolitical thinkers, such as Henry Kissinger and Zbigniew Brzezinski offered the "Finnish model" as an option to solve the Ukrainian question. ${ }^{33}$ According to Kissinger's idea, Ukraine should internationally pursue a posture comparable to that of Finland during the Cold War which would mean that Ukraine should "...leave no doubt about its fierce independence it would cooperate with the West in most fields but carefully avoid institutional hostility toward

25 Palosaari 2013.

26 Raik et al. 2015.

27 Ojala and Kaasik-Krogerus 2016.

28 Haukkala 2010.

29 Ibid.

30 Pesu 2018.

31 Ibid.

32 President of Finland (a) 2017.

33 Kissinger 2014, quoted in Järvenpää 2015. 
Russia" ${ }^{34}$ Another thought-provoking article by Mikheil Saakashvili, former president of Georgia, found the northern parts of Finland or Swedish Gotland as "perfect" next targets for Russia as both share the proximity with Russia but as non-members of NATO they will not present the "land to fight for." ${ }^{35}$ Saakashvili's elaboration was responded by Jyri Raitasalo, a professor of Finnish National Defence University, who argued that Shaakasvili's argument inflated the threat level and had flawed analysis, and was not a realistic understanding of interstate relations in Northern Europe today. ${ }^{36}$ Prof. Raitasalo's reply also stated that Finland is one of the few that can use the tools of diplomacy while having also preserved its warfare capabilities. ${ }^{37}$

According to Mika Aaltola, instead of balancing, Finland has started to see itself as a stabilizer of the regional geopolitical situation that should not change its foreign policy to destabilize the overall situation in the Baltic Sea region. ${ }^{38}$ According to Aaltola, after the annexation of Crimea, the key term in Finnish foreign policy has become "NATO-possibility". By that Finland reserves the right to decide its security alliance or non-alliance, if the situation so requires, Finland can choose to align itself. Thus, the annexation of Crimea and the war in Ukraine have meant multilevel challenges to Finland that in turn has challenged its location on a geopolitical map. ${ }^{39}$

\section{Estonia: A Transatlantic Small State, Is That Enough For the Challenging Neighbourhood?}

After having its independence restored in 1991, Estonia chose to emphasize its legal continuity of the pre-Second world war republic. During its re-independence period, Estonia has acknowledged its political smallness more than during its first independence. According to Vahur Made, during the first independence period, Estonia pursued a bilateral relations-based foreign policy that has been replaced with a strong multilateral foreign policy. ${ }^{40}$ Due to its geopolitical location, Estonia has been able to pursue dual foreign policy identities - Baltic and Nordic, usually focused on Nordic that has slightly been substituted by "European". All three have been beneficial to gain visibility and increase knowledge about Estonia on the world map to avoid the "mentality of Yalta". Therefore, Estonia's foreign policy, since the restoration of independence, took an opposite direction from pre-war foreign policy. It could be titled "never alone again" meaning a clear and strong direction towards the West. Though every foreign policy is always based on important choices, Estonia is a case where foreign policy action space and alternatives to

\footnotetext{
34. Ibid.

35 Saakashvili 2019.

36 Raitasalo 2019.

37 Ibid.

38 Aaltola, Mika. Interview, 2019.

39 Ibid.

40 Made 2019.
} 
Western integration were minimal. Geography, size, and history have all played an important role in adopting a Western-oriented foreign policy line. Therefore, as a small country in a complicated strategic location in geopolitical space, Estonia has declared belonging into collective systems as the only way to secure its independence and sovereignty. Thus, in contrast to Finland, in the Estonian case, the dream about being a "bridge" between the West and Russia has never been a serious option.

The institutional framework of Estonian foreign policy rests on three institutional pillarsthe execution of foreign policy is carried out by the government (prime minister/foreign minister/foreign ministry), legislative part by the parliament (including also the work of the permanent parliamentary committee of foreign affairs) and also by the president who fulfils a rather ceremonial role (diplomatic appointments and credentials, state visits).

Throughout the post-Cold War era, Estonia has managed to keep a strong political consensus on its direction towards the West. This meant a commitment to a multilateralismbased foreign policy and a policy of integration, which fulfilled its aim not to be alone. For the success of integrating into NATO, Estonia has decided to follow the foreign policy path of a "transatlantic small state" by participating in international missions. Though the mission in Iraq was not about Estonia bringing democracy to Iraq but an opportunity to enhance Estonia's relations with its allies. Therefore, locating Estonia in the West has also come with multilevel costs- financial, human loss and violating international law. Still, the chosen foreign policy way has never been much debated in Estonian domestic politics.

The annexation of Crimea brought a new, domestic dimension into Estonian foreign policy discourse, started by western journalists who asked whether Narva, would be the "next" ?41 Narva, a city in Eastern Estonia whose population by 1 January 2020 mostly consists of Russian speakers $(83 \%)^{42}$ and whose population is divided between citizens and non-citizens (Russian citizens $36 \%$ and grey passport holders 13,6\%, Estonian citizens $48 \%)^{43}$ presented an excellent case for theorists and journalists to play with the idea whether World War III could start from Narva. The Estonian response to the internationally posed question came from Andres Kasekamp, a professor of Tartu University at the time who noted the different living standards in Russia and Estonia, the latter having a higher standard of living in all the major categories. ${ }^{44}$ Kasekamp also highlighted Estonia's privilege of being a member of NATO and the EU, which Ukraine, of course, was not.

The conflict in Ukraine and the annexation of Crimea forced Estonia to reconsider its selfdefence capabilities and to pay more efforts to integrate the Russian speakers into its own media sphere. As a result of the Ukrainian crisis, Estonia together with Baltic neighbours, Poland and Romania, demanded a more robust show of support from NATO. As a result

\footnotetext{
41 Berman 2014.

42 Invest in Narva factsheet 2020.

43 Ibid.

44. Kasekamp 2015.
} 
of the war in Eastern Ukraine, there have been additional allies coming to Estonia since 2014. For a small state, it was a big political win as the U.S. reversed its Asia-Pacific pivot ${ }^{45}$ back to Europe, and NATO to focus on protecting European countries.

\section{Practical Geopolitical Reasoning of the Role of the Annexation of Crimea and War in Ukraine in Estonian and Finnish Foreign Policy Discourses}

According to Raik et al., ${ }^{46}$ the crisis in Ukraine re-introduced old geopolitical constraints and concerns about national security and sovereignty, limiting room to manoeuvre for small states. The Finnish way of seeing Estonians as too sharp on Russia and Estonians seeing Finns too friendly with Russia ${ }^{47}$ were evident when after the annexation of Crimea president Obama visited Tallinn in September 2014 and delivered a passionate speech reassuring the commitment of NATO towards Baltic security. This created a sharp contrast with Finnish president Niinistö's meeting with Putin in Sochi in August 2014 that he reasoned as a necessary visit to keep the communication going even if the news was bad. ${ }^{48}$ While Estonia was on the frontline of supporting harder sanctions against Russia, the Finnish debate was on the effectiveness and political usefulness of sanctions against Russia. ${ }^{49}$ As Finland and Estonia differ in their memberships in international organizations, it might be concluded that due to that they have also interpreted the parties of the Ukrainian crisis differently. In Estonian foreign political discourse, the war in Ukraine and the annexation of Crimea were interpreted as a crisis between Russia and Ukraine, not a civil war, with the possibility to send weapons to support Ukraine. ${ }^{50}$ From a Finnish perspective, Russian actions in Ukraine have been sharply condemned but the annexation of Crime and war in Eastern Ukraine have been interpreted in a broader context compared to Estonia. The Finnish reasoning has seen the developments in Ukraine as something that took place due to mistrust and opposition that also needs a broader response by the EU, which could be done by developing the Common Security and Defence Policy of the EU. ${ }^{51}$ In addition to leaving space to blame the West, Finland also condemns Russia's actions in Ukraine with the remark that cooperation is necessary for the future. Thus, the Finnish foreign policy line includes a multi-optional response. Leaving the door open for future cooperation presents a major difference in foreign policy reasoning between the two countries. By locating itself clearly in the West, Estonian foreign policy thinkers do not find it possible to have strategic(official and political) level cooperation or dialogue with Russia unless Russia returns Crimea to Ukraine, though practical and administrative

\footnotetext{
45 Allen 2009.

46 Raik et al. 2015.

47 Raik 2018.

48 President of Finland (b) 2017.

49 Raik et al. 2015.

50 Parliament of Estonia 2015.

51 President of Finland (c) 2014.
} 
level cooperation between Estonia and Russia still runs. As indicated in Estonian 2017 Foreign and Security Policy Concept, the EU sanctions towards Russia have enhanced deterrence but rebuilding trust and cooperation depends on how Russia decides to deescalate the conflicts where it is involved..$^{52}$

Finland, on the other hand, presents its worries about the future and hopes to maintain cooperation with Russia in Arctic matters. ${ }^{53}$ Thus, when comparing the practical geopolitical reasoning of Estonian and Finnish foreign policies, the Estonian one could be characterized as more assertive towards Russia and straight forward in engaging its allies while the foreign policy of Finland as multi-faced - supporting EU sanctions but also cautious to retain common ground for future dialogue with Russia. In addition to Estonia's determined support for Ukraine, both on the bilateral level and also in the framework of EU's Eastern Partnership Initiative, ${ }^{54}$ Estonia has been a strong advocate for the EU's unity in sanctions against Russia. Estonia's determined behaviour for the sanctions is also reflected in its initiative to create an application that enables interested parties to better recognize the sanctioned persons. ${ }^{55}$

Estonia's aim to locate itself as far as possible in the West means as far away as possible from Russia. That again differs in Finnish foreign policy discourse where one can find the memories of being part of the great, Tsarist Empire. ${ }^{56}$ For example, in January 2017 president Niinistö reminded Petro Poroshenko, former president of Ukraine, during his visit to Helsinki, the common past of Finland and Ukraine by saying "one hundred years ago Finland and Ukraine were still parts of the same empire ...."57 That is a rhetoric, which is rarely, if ever found in the Estonian foreign policy discourse, as the past and being part of tsarist Russia or the Soviet Union is not considered a positive element in foreign policy.

Another major difference in how the events in Ukraine were differently perceived and reasoned can be seen by placing these events into a wider international relations context. In Estonian foreign policy discourse, the events in Ukraine are strongly presented as a continuation of the War in Georgia in 2008. In Finnish discourse, based on the researched materials, the developments in Ukraine were not reasoned as a continuation of what took place in Georgia in 2008 or even in the same context. Rather opposite examples can be found-in his speech at UNGA president Niinistö described the war in Ukraine as a crisis that has a deep impact on the security of Europe, a breakdown that we have not experi-

\footnotetext{
52 Ministry of Defence of Estonia 2017.

53 President of Finland (d) 2015.

54 In 2011, the Ministry of Foreign Affairs of Estonia together with Estonian School of Diplomacy established the first center on Eastern Partnership in EU countries, Estonian Center of Eastern Partnership.

55 Ministry of Foreign Affairs of Estonia 2018.

56 President of Finland (e) 2017.

57 Ibid.
} 
enced since the tragedy of Balkan wars. ${ }^{58}$ After the annexation of Crimea similarly, in the foreign policy discourses of both countries, they both perceived themselves as possible next targets for Russia, which made them pursue active foreign policies and engagement with the West. From the Estonian perspective, it meant more NATO and more cooperation between the EU and NATO, also strengthening bilateral relations with the U.S. For Finland, it meant more EU common defence and security policy, also leaving some space for the "NATO option" and strategic communication with Russia.

The empirical contribution of this study builds an understanding of how the developments in Ukraine impacted both countries' locations and aspirations in geopolitical space. Based on the literature review, an interview and the analysis of both countries' foreign policy strategies and foreign policy speeches, the materials were analysed by creating subdivisions based on the three research questions that were developed with the help of practical geopolitical reasoning, to be elaborated in following.

The first research question aimed to understand to where the annexation of Crimea and war in Eastern Ukraine locate Estonia and Finland in geopolitical space. Here, both countries saw themselves as members of the Western community with the EU as their first political identity and sanctions against Russia as its main outcome. Views differed on security and defence, where Estonia saw itself as a core member of NATO, one of the few fulfilling the $2 \%$ defence spending criteria. Finland from the other hand emphasized the importance of EU level security and defence cooperation to strengthen it. In terms of more concrete locations on geopolitical map, after the annexation of Crimea, Estonia started to see itself even more firmly as a part of Western society, but also as a country located in a geopolitically very difficult region. Finland from the other hand saw itself as a bridge between West and Russia, to keep the dialogue open with Russia. The high peak of Finnish efforts arrived in July 2018 when Finnish president Niinistö hosted the TrumpPutin Summit in July 2018 in Helsinki. ${ }^{59}$ Thus, Finland saw itself rather as a stabilizer of the Baltic Sea region, a country with a geopolitically strategic position and location.

Already before the annexation of Crimea, Estonia supported the EU accession of the countries of Eastern Partnership through the support for reforms and humanitarian aid, where Ukraine was one of the priority countries. After the annexation of Crimea, the support became even more political which is reflected in foreign policy concepts and annual foreign policy debates. When it came to stands vis-à-vis to Ukraine, Estonia saw itself located on Eastern wing that meant being on the same wing together with Ukraine. This geopolitical identification can be explained from different angles. First, due to the changed security environment in Eastern Europe, it meant that Estonia, together with other Baltic states and Poland, received NATO's enhanced military presence on a rotational basis decided at the Warsaw Summit. ${ }^{60}$ Post-Crimean additional security assurances are indicated

58 President of Finland (f) 2014.

59 ERR 2018.

60 NATO 2017. 
in Estonia's 2017 Foreign and Security policy concept that declares that to have credible deterrence there needs to be equipped allied presence in Estonia and its vicinity ${ }^{61}$ Second, for Estonia, the worrisome developments in Ukraine set the future of Ukraine together with the future of the Eastern Partnership under question. This was of particular importance to Estonia, as the Eastern Partnership Initiative, adopted in 2009 under the EU's European Neighbourhood Policy served as Estonia's main post-EU accession foreign policy interest. As stated in 2015 by Marko Mihkelson, Chairman of Foreign Affairs Committee of Estonian Parliament - „Ukraine has been central foreign policy interest for Estonia for years, it is in our interest to continue to support the democratic developments in Ukraine as a stable and successful Ukraine increases security in whole Europe". ${ }^{62}$ Another statement by Minister of Foreign Affairs at the time, Keit Pentus-Rosimannus emphasized that the war in Ukraine takes place only $2000 \mathrm{~km}$ from Estonia, which needs to be mitigated by two-hold Estonian reaction - political support and consistent pressure in the form of EU sanctions. ${ }^{63}$ Third, more commonly spread reasonings found historical parallels where the occupation of Crimea under Russia was seen similar to the occupation of Estonia under the Soviet Union, thus, the non-recognition of Crimea as part of Russia was seen as equal to the Western non-recognition policy of Baltic states under the Soviet Union.

To conclude the findings of the first research question, both states saw themselves as core members of the West who needed to deal with the new security environment but what exactly is the West and how to do that remained somewhat different. From the Estonian perspective, the fate of Ukraine and its future was seen more as a development that will have an impact on Estonia's future as Estonia rather perceived itself as a participant not the monitoring body or a mediator of the Ukrainian crisis. Estonia saw itself as a core member of transatlantic cooperation, including both, membership of the EU and NATO. Finland in turn firmly indicated itself as a member of the EU and a core supporter of the EU's common security and defence policy. Both countries as neighbours of Russia condemned the annexation of Crimea and saw Russia as an aggressor, but due to different historic experiences, Finland, as opposed to Estonia, saw dialogue with Russia to find a solution to the crisis in Ukraine, possible. Thus, different roles could be given to both countries - Finland as an observer but also an active mediator of the conflict that needed a solution and Estonia as an active participant of the crisis, whose future was related to the solution of the crisis in Ukraine.

The second question analysed the direct impact of the annexation of Crimea and Russia's actions in Ukraine in the foreign policy reasoning of Estonia and Finland. The most direct and crucial impact was that parts of both countries' territories became a subject of discussion as possible next objects of Russia's actions. In Estonia, the possible next object became the Eastern city of Narva that has a high number of Russian speaking and noncitizen population. These discussions even elaborated that Narva would suit as a "perfect

61 Ministry of Defence of Estonia 2017.

62 Parliament of Estonia 2015.

63 Ibid. 
testing material" for NATO's Article 5. On the Finnish side, the Åland Islands, a set of Islands between Sweden and Finland and a crucial spot for shipping routes were mentioned as the next possible target. An important difference arose from these reasonings as in the case of Estonia, Narva as the "possible next" was never mentioned in any official foreign policy documents. Instead, this question was brought up by international media that became a hot topic of international media and academic discussions. In the case of Finland, the attack of Åland Islands was brought, with a cautious wording but still, in Governmental 2016 report with a wording; "a direct attack cannot be excluded". Also, Estonia perceived the events in Ukraine as a continuation of the war in Georgia in 2008, while in the Finnish perspective the events in Ukraine were never mentioned in the same context with the War in Georgia. The reflection of the past remains different in both countries' foreign policies but comes alive due to the developments in Ukraine and is heavily impacted by the levels of international alignment, specifically NATO membership.

The third question focused on the wider impact the annexation of Crimea and war in Eastern-Ukraine had brought to Finnish and Estonian foreign policy paradigms. Both, Estonia and Finland apply the small state perspective in their foreign policies, that are dependent on the external environment, but these two countries are impacted by the external environment more than usual as they share border with Russia. Events in Ukraine led to worrisome discussions in both countries. Estonian foreign policy documents and discussion papers reflect a troubling look into the future that sees the events in Ukraine weakening the international rules-based order that Estonia is reliant on. In Estonian foreign policy reasoning, a parallel was also drawn with the migration crisis that together with the events in Ukraine decreased the attractiveness of the European value system. In Finnish foreign policy, the discussion focused on the future of the EU as a security and defence actor and encouraged to have more EU level security and defence cooperation. If Estonian foreign policy reasoning looks into the future and sees it based on the unity of the EU, and NATO, then Finnish foreign policy reasoning builds the future on the EU as a political and as a security and defence actor, and on the NATO-possibility, should it become necessary. This was demonstrated in 2016 when Finnish minister of defence Jussi Niinistö said that in the event of an international crisis Finland would come to the aid of Estonia if needed and that would be done within the framework of the EU. ${ }^{64}$ 


\section{Conclusion}

This article analysed how Estonia and Finland, two neighbouring small states, "left alone" in their perceptions of history, have applied the "alone" feature differently in their foreign policies. Thus, this article was interested in small state foreign policy moves they apply in geopolitical space to be on the winner's side.

Developments in Ukraine- the annexation of Crimea and war in Eastern Ukraine were selected as external outputs to study the small state foreign policy reasoning with the help of applying practical geopolitical reasoning. A study of O'Tuathail and his toolkit of geopolitical grammar was selected as an example to develop three sub-research questions.

The first question asked where the developments in Ukraine located the two neighbouring small states in geopolitical space. Based on studied documents, materials and an interview, both countries, as members of the West condemned Russia's actions and supported EU sanctions. Due to the crisis in Ukraine, both countries pursued active foreign policies but adopted somewhat different roles, as they perceived their geographic location differently. Estonia perceived itself as a small state with one of the most difficult geopolitical location, based on that and historic experience, Estonia perceived itself as a participant of the crisis in Ukraine. Finland perceived itself as a small state with a geopolitically strategic location, based on the developments and its historic experience, Finland perceived itself rather as a mediator and observer.

The second research question was interested in the direct impacts the annexation of Crimea and war in Eastern Ukraine have meant for Estonia and Finland. Here, similarly, both countries tried to adapt to changing security environment and saw parts of their territories as possible next destinations for some level attack. Estonia as a member of NATO received Alliances enhanced presence that paralleled the discussion on "NATOpossibility" in Finland.

The third research question was interested in the indirect consequences of post-2014 developments in both countries. However, Estonia saw itself as a member of West based on transatlantic partnership; Finland relied on an EU-based West with the EU as a credible defence actor.

Estonia and Finland have relied on defence narratives that have been shaped by their geopolitical locations both in the past and in present. Estonia's "never alone" and Finland's "always alone" have guided their foreign policies. Setting aside NATO membership the geopolitical position of Estonia and Finland has become more similar, - their foreign and defence policies have begun to merge as well. Yet, differences remain in both policy and style. Both countries' foreign policy heavily influenced geographical location but developed it in different ways. 
For Estonia, the lesson of never alone has meant an aggressive strategy to become a valued member in the eyes of key allies. Estonia's policies have aimed at keeping the EU and NATO unified and engaged in the region. Despite the emphasis on alliance solidarity, Estonia never gave up on territorial defence and continued to invest in defence capabilities, including maintaining military conscription.

For Finland, the lesson of always alone has meant a focus on its territorial defence, including military conscription and a policy of non-alignment. In the post-Cold War era, Finland has slowly shifted towards alignment; joining the EU and enhancing relations with NATO. Despite the movement towards multilateral defence communities and alliances, Finland maintains its hold as a pragmatic negotiator and force for stability in the region.

While Estonia located itself firmly into the West and did not believe in any serious level of cooperation or dialogue with Russia then Finland located itself as a member of the EU and saw dialogue with Russia as a vital part of its foreign policy. This changed after the annexation of Crimea but differently from Estonia's perspective which placed the blame only on Russia, from Finnish perspective the conflict in Ukraine and annexation of Crimea were both seen as a cause and as a consequence of a broader crisis between Russia and the West. As Estonia and Finland's defence policies slowly come closer together, the differences in geopolitical positions, both past and present ensure that some differences will remain. 


\section{References}

Allen, Mike. 2009. “America's first Pacific president”. Politico, 13 November 2009.

Accessed February 24, 2020. https://www.politico.com/story/2009/11/americas-firstpacific-president-029511.

Berman, Daniel. 2014."Will Narva Be Russia’s Next Crimea?", the Diplomat.

Accessed August 21, 2019. https://thediplomat.com/2014/04/will-narva-be-russiasnext-crimea/.

Browning, Christopher R., and, Marko Lehti. 2007."Beyond East-West: Marginality and National Dignity in Finnish Identity Construction." Nationalities Papers 35 (4): 691-716.

Estonian Center of Eastern Partnership. Accessed February 22, 2020. www.eceap.eu.

Finnish Defence Forces. Accessed December 23, 2019. https://puolustusvoimat.fi/en/ international-activities/natos-partnership-for-peace-programme.

Forsberg, Tuomas, and Matti Pesu. 2016. “The 'Finlandisation' of Finland: The Ideal Type, the Historical Model, and the Lessons Learnt." Diplomacy \& Statecraft 27 (3): 473-495.

Government Report on Finnish Foreign and Security Policy. 2016. Accessed December 22, 2019. https://um.fi/publications/-/asset_publisher/TVOLgBmLyZvu/content/ government-report-on-finnish-foreign-and-security-policy.

Haukkala, Hiski. 2010. "Finnish Foreign policy: a brief info." Accessed August 18, 2019. https://finland.fi/life-society/finnish-foreign-policy-a-brief-intro/.

Hey, Jeanne A.K. 2003. Small States in World Politics. Explaining foreign policy behavior. London: Lynne Reinner publishers.

Invest in Narva Factsheet. Accessed February 22, 2020. https://www.investinnarva. ee/et/narvast/ldinfo/rahvastik.

International Sanctions. Ministry of Foreign Affairs of Estonia. 2018. Accessed February 23, 2020. https://vm.ee/en/international-sanctions.

Järvenpää, Pauli. 2015. „Finland in 2014: Between a Rock and a Hard Place.“ Accessed September 9, 2019. https://icds.ee/wp-content/uploads/2014/Pauli_Jarvenpaa_-_Finland_in_2014.pdf. 
Kasekamp, Andres I. 2015. „Why Narva is not next“, Estonian Foreign Policy Institute Paper Series No. 21. Accessed July 18, 2019. https://www.eesti.ca/narva-is-not-nextkasekamp-says/article45026.

Knudsen, Olav F. 1996. "Analyzing Small-State Security: The Role of External Factors." In Small States and Security Challenge in the New Europe, edited by Werner Bauwens, Armand Clesse, and Olav F. Knudsen, 3-20. London and Washington D.C.: Brassey's.

Made, Vahur. 2019. “Eesti välispoliitika 100 aastat”, Post Factum publisher.

Ministry of Defence of Estonia. 2017. "Eesti Vabariigi Julgeolekupoliitika alused." (Foreign and Security policy concept). Accessed December 23, 2019. http://www. kmin.ee/sites/default/files/sisulehed/eesmargid_tegevused/395xiii_rk_o_lisa.pdf.

NATO Fact Sheet. Warsaw Summit Key Decisions. February 2017. Accessed February 21, 2020. https://www.nato.int/nato_static_fl2014/assets/pdf/ pdf_2017_02/20170206_1702-factsheet-warsaw-summit-key-en.pdf/.

Noreen, Erik, Roxana Sjöstedt, and Jan Ångström. 2017. "Why small states join big wars: the case of Sweden in Afghanistan 2002-2014." International Relations 31 (2): 145-168.

Ojala, Markus M., and Sigrid Kaasik-Krogerus. 2016. "Popular Geopolitics in the Shadow of Russia: The Ukraine Conflict in Finnish and Estonian Newspaper Editorials." In Media and the Ukraine Crisis: Hybrid Media Practices and Narratives of Conflict, edited by Mervi Pantti, 139-155. New York: Peter Lang.

O'Tuathail, Gerard. 2002. "Theorizing practical geopolitical reasoning: the case of the United States' response to the war in Bosnia." Political Geography 21 (5): 601-628.

Palosaari, Teemu. 2013. "Still a Physician rather than a Judge? The Post-Cold War Foreign and Security Policy of Finland." Swiss Political Science Review 19 (3): 357375.

Parliament of Estonia. 2015. Annual Foreign policy debate. Accessed September 6, 2019. http://stenogrammid.riigikogu.ee/et/201502121000.

Parliament of Estonia. 2016. Annual Foreign policy debate. Accessed December 23, 2019. http://stenogrammid.riigikogu.ee/et/201602111000\#SND-3104349.

Parliament of Estonia.2017. Annual Foreign policy debate. Accessed February 23, 2020. http://stenogrammid.riigikogu.ee/et/201702091000\#PKP-20295. 
Pesu, Matti. 2018. “What Sauli Niinistö’s re-election means for Finnish foreign policy."

Accessed September 1, 2019. https://www.fiia.fi/julkaisu/what-sauli-niinistos-reelection-means-for-finnish-foreign-policy.

President of Finland (a). Speech by President of the Republic Sauli Niinistö on the Flag Day of the Finnish Defence Forces in Helsinki on 4.06.2017. Accessed September 17, 2019.

https://www.presidentti.fi/en/speeches/speech-by-president-of-the-republic-sauliniinisto-on-the-flag-day-of-the-finnish-defence-forces-in-helsinki-on-4-june-2017/.

President of Finland 2017 (b). Presidential press release "President Niinistö after visiting Russia and Ukraine: Open line of communication needed". https://www. presidentti.fi/en/news/president-niinisto-after-visiting-russia-and-ukraine-openline-of-communication-needed/ [12.09.2019]

President of Finland 2014 (c). Presidential press release "President Niinistö to Finnish ambassadors: The diplomatic challenge now extends beyond Ukraine". Accessed September 2, 2019.

https://www.presidentti.fi/en/news/president-niinisto-to-finnish-ambassadors-thediplomatic-challenge-now-extends-beyond-ukraine/.

President of Finland 2015 (d). Speech by President of the Republic Sauli Niinistö at the diplomatic dinner held at the Presidential Palace. 23.04.2015. Accessed August 23, 2019. https://www.presidentti.fi/en/speeches/speech-by-president-of-the-republic-sauli-niinisto-at-the-diplomatic-dinner-held-at-the-presidential-palace-on23-april-2015/.

President of Finland 2017 (e). Speech by the President of the Republic Sauli Niinistö at a dinner in honor of the President of Ukraine at the Presidential Palace in Helsinki on 24.01.2017. Accessed August 23, 2019. https://www.presidentti.fi/en/speeches/ speech-by-the-president-of-the-republic-sauli-niinisto-at-a-dinner-in-honourof-the-president-of-ukraine-at-the-presidential-palace-in-helsinki-on-24th-janu$\operatorname{ary}-2017 /$.

President of Finland 2014 (f). Statement by President of the Republic Sauli Niinistö at the UNGA 69th General Debate on 24 September 2014. Accessed February 24, 2020. https://www.presidentti.fi/en/speeches/statement-by-president-of-the-republicsauli-niinisto-at-the-unga-69th-general-debate-on-24-september-2014/. 
Raik, Kristi. 2018. "How to Talk About and With Russia? Estonia Has a Thing or Two to Learn From Finland”, ICDS blog. Accessed December 23, 2019. https://icds. ee/how-to-talk-about-and-with-russia-estonia-has-a-thing-or-two-to-learn-fromfinland-about-communicating-with-our-eastern-neighbour/ [23.12.2019], blog -post based on anarticle at Kaleva.fi, https://www.kaleva.fi/mielipide/kolumnit/mitenpuhua-venajasta-ja-venajan-kanssa/807487/.

Raik, Kristi, Mika Aaltola, Mika; Katri Pynnöniemi, and Charly Salonius-Pasternak. 2015. "Pushed together by external forces? The foreign and security policies of Estonia and Finland in the context of the Ukraine crisis" FIIA briefing paper no.167.

Raitasalo, Jyri. 2019. "Scandinavia Won't Be Russia's Next Target." Accessed August 30, 2019. https://foreignpolicy.com/2019/03/27/scandinavia-wont-be-russias-nexttarget-putin-nato-finland-sweden-defense-saakashvili-georgia/.

Saakashvili, Mikheil. 2019. "Russia's Next Land Grab Won't Be in an Ex-Soviet State. It Will Be in Europe." Foreign policy. Accessed September 2, 2019. https://foreignpolicy.com/2019/03/15/russias-next-land-grab-wont-be-in-an-ex-soviet-state-it-will-bein-europe-putin-saakashvili-sweden-finland-arctic-northern-sea-route-baltics-nato/.

Sakkov, Sven. 2019. "A View From the Frontline: Estonian Experience." In „The Alliance Five Years After Crimea: Implementing the Wales Summit Pledges." NATO Defence College, Research Paper \#7, edited by Marc Ozawa. Accessed February 22, 2020. https://icds.ee/a-view-from-the-frontline-estonian-experience/.

Trump, Putin meet in Helsinki, ERR liveblogged event. ERR. Accessed February 23, 2020. https://news.err.ee/846924/trump-putin-meet-in-helsinki-err-livebloggedevent.

Vaicekauskaitè, Živile M. 2017.'Security Strategies of Small States in a Changing World." Journal on Baltic Security 3 (2): 7-15.

Vahur, Lauri. 2016. "Jussi Niinistö: Finland as EU member would aid Estonia in crisis”. ERR.ee. 17.06.2016. Accessed December 21, 2019. https://news.err.ee/118361/ jussi-niinisto-finland-as-eu-member-would-aid-estonia-in-crisis.

An interview was conducted with Dr. Mika Aaltola (Director of Finnish Institute of International Affairs, professor at Tallinn University) on July 31, 2019. 